\title{
Husband's Education Level and Alcohol Drinking Habit as Risk Factors of HIV Infection among Housewives in Pati District
}

\author{
Tingkat Pendidikan dan Kebiasaan Mengonsumsi Alkohol Suami sebagai \\ Faktor Risiko Infeksi HIV pada Ibu Rumah Tangga di Kabupaten Pati
}

Nurul Aeni*, Annemarie Westendorp**

*Local Development Planning Agency of Pati District, Pati, Indonesia, **Faculty of Management of Development, Van Hall Larenstein University of Applied Science, Larensteinselaan, The Netherland

\begin{abstract}
Cases of Human Immunodeficiency Virus (HIV) infection in Pati District increase, particularly among housewives. The aim of this study was to analyse the risk factors of HIV infection among housewives in Pati District using case-control study design. The respondents were 90 housewives divided into case and control group. The case group consisted of 30 housewives living with HIV, while the control group comprised 60 housewives living in the similar area of the counterparts. The data collection was focused on demographic, sexual behaviour, and sociocultural variables possessed by housewives and their husbands. The study resulted that the risk factors of HIV infection among housewives based on bivariate analysis were housewife's level of education, husband's level of education, husband's occupation, housewife's sexual transmission disease (STD) record, husband's STD record, husband's participation in religious activities, and husband's alcohol drinking habit. The risk factors that fitted to logistic regression model were education level and alcoholic behaviour of husbands that contributed to $29.1 \%$ HIV infection among housewives. In conclusion, the husband's variables are proved having stronger and very significant correlation with HIV infection among housewives than housewife's variables.
\end{abstract}

Keywords: Alcohol drinking habit, education level, hiv, husband

\begin{abstract}
Abstrak
Kasus infeksi HIV di Kabupaten Pati menunjukkan peningkatan khususnya pada kelompok ibu rumah tangga (IRT). Penelitian ini bertujuan menganalisis faktor risiko penularan HIV pada ibu rumah tangga di Kabupaten Pati dengan desain penelitian kasus kontrol. Jumlah responden adalah 90 IRT yang terbagi dalam kelompok kasus dan kelompok kontrol. Kelompok kasus terdiri dari 30 IRT yang terinfeksi HIV, sedangkan kelompok kontrol terdiri dari 60 IRT yang tidak terinfeksi HIVdan tinggal di desa yang sama dengan responden pada kelompok kasus. Pengumpulan data difokuskan pada variabel demografi, perilaku seksual, dan sosial budaya yang melekat pada IRT dan suami. Hasil penelitian menunjukkan bahwa faktor risiko infeksi HIV pada IRT berdasarkan analisis bivariat adalah tingkat pendidikan IRT, tingkat pendidikan suami, pekerjaan suami, riwayat penyakit infeksi menular seksual (IMS) IRT, riwayat IMS suami, partisipasi suami dalam kegiatan keagamaan, dan kebiasan suami mengonsumsi alkohol. Variabel yang sesuai dengan model regresi logistik adalah tingkat pendidikan suami dan kebiasaan suami mengonsumsi alkohol, dimana kedua variabel memengaruhi 29,1\% kasus infeksi HIV pada IRT. Disimpulkan bahwa variabel yang melekat pada suami memiliki signifikasi dan korelasi yang lebih kuat terhadap infeksi HIV dibandingkan kelompok IRT.
\end{abstract}

Kata kunci: Kebiasaan mengonsumsi alkohol, tingkat pendidikan, hiv, suami

How to Cite: Aeni N, Westerndorp A. Husband's education level and alcohol drinking habit as risk factors of HIV infection among housewives in Pati District. Kesmas: National Public Health Journal. 2017; 12(2): 60-66. (doi:10.21109/kesmas. v12i2.1704)
Correspondence: Nurul Aeni, Local Development Planning Agency of Pati District, Pati-Kudus Street Km. 4, Pati 59163, Phone: +62295-351381, e-mail: aeni_240884@yahoo.co.id

Received: August 29th 2017

Revised: October $13^{\text {th }} 2017$

Accepted: October $16^{\text {th }} 2017$ 


\section{Introduction}

The spreading of Human Immunodeficiency Virus (HIV) infection around the world can be considered as an iceberg phenomenon. United Nation of Acquired Immunodeficiency Syndromes (UNAIDS) revealed that until 2015, the number of people living with HIV reached about 36.7 million people. ${ }^{1}$ The efforts to slow down the spread of HIV has been doing massively, but several countries still showed a significant increase of HIV infection. UNAIDS reported that in 2014, the increase of new case of HIV infection in Indonesia reached $48 \%$. It became one of the highest in Asia Pacific. ${ }^{2}$ The report from The Ministry of Health report showed that from April 1987 to September 2014, there were 206,095 people living with HIV/AIDS, while the death caused by AIDS reached 9,796 people. ${ }^{3}$

The Ministry of Health revealed that heterosexual intercourse is the main factor of HIV transmission in Indonesia. ${ }^{3}$ The number of men living with HIV exceeds the number of women. Interestingly, the rate of new HIV transmission cases among women is higher than that men. In 2008, the ratio of women and men living with HIV was 1:2, while in 2014 that became 7:10. ${ }^{2}$ Women are more vulnerable for being infected with HIV compared to men. Ostrach and Singer, ${ }^{4}$ mentioned that the vulnerability came from both biological and social factors. Furthermore, that study stated that there is an interconnection between both factors, and even several factors are overlapped, so the explanation of the determining factors of HIV infection among women becomes more complex. Rombo, ${ }^{5}$ categorized the risk factors of HIV infection among women into demographic, sexual behavior, and socio-cultural factors. Physically, women are more vulnerable being infected by HIV. The biological processes, including hormonal changes during menstruation, pregnancy, menopause, and hormonal contraception increase the vaginal vulnerability to the development of lesion, which ease HIVs entering woman's body. ${ }^{4-7}$

The social factors, like poverty, indirectly increase the woman's vulnerability to HIV infection. Poverty raises the woman risk acquiring HIV due to lack of access to health care. ${ }^{4}$ Another study proved that gender inequality improves the woman's vulnerability to HIV infection. ${ }^{8}$ The women being infected with HIV are likely to have a high economic dependency. This situation causes women have lower bargaining position in the households, includes requiring safe sexual behaviors. Among women, housewives are the most vulnerable group for being infected by HIV. Based on the Ministry of Health report, it was estimated that the number of housewives living with HIV was doubled in the period 2011-2014. ${ }^{1}$ Until September 2014, the number of housewives living with HIV reached more than 6,500 women and placed them in the second group with the highest number of HIV infection in Indonesia.

Similar situation was found in Pati District, Central Java. Pati was one of districts in Central Java with the rapid increase of HIV infection. The statistical report from the Health Service mentioned that the number of men living with HIV was higher compared to women and found in all subdistricts. However, during the period 2013-2014, more than 50\% newly HIV infection cases were found among women, especially housewives. 9,10 Therefore, housewives became the second highest HIVinfected group following business person group. Interview with a national goverment organization (NGO) concerning on women living with HIV named Rumah Matahari revealed that about 59\% women living with HIV, who were supported by Rumah Matahari, are housewives.

Regarding those situations, the spread of HIV infection among housewives has become a serious issue. Beijing Declaration and Platform for Action stated that in poor and developing countries, HIV transmission has greater impacts on women compared to men. ${ }^{11} \mathrm{HIV}$ transmission among women affected the woman's roles, such as parenting, child bearing, and income earning. For instance, if the woman in a household is infected by HIV, the household's economy could collapse, then it influences the quality of life of the rest members'. 12 WHO mentioned that without any intervention, the rate of mother-to-child HIV transmission ranged from 15 to $45 \% .{ }^{13} \mathrm{~A}$ study in eight provincial capitals in Indonesia reported that the prevalence of HIV infection among pregnant women was $0.41 \%$. That number was higher than the prevalence in developed countries although far lower than that in African countries. ${ }^{14}$ The impacts were worsened since HIV infections were mostly found at the productive age as per reported by the Ministry of Health. It was about $60 \%$ people living with HIV were in age ranged of 20-39 years old. ${ }^{1}$ While the data from Rumah Matahari, reported about $63 \%$ women living with HIV aged 21-45 years old. The objective of this study was to examine the demographic, sexual behavior, and sociocultural variables possessed by housewives and husbands that are potentially effect the HIV infection among housewife.

\section{Method}

Using case-control study design, this study was conducted in Pati District. The data were collected during March-August 2015. The number of respondents were 90 women divided into two groups, case and control group. The ratio of the two groups respectively was $1: 2$. The respondents in the case group were 30 consisting of the housewives living with HIV/AIDS. The naming were given by the NGO Rumah Matahari. The control group 
comprised of housewives living in similar area with case group respondents of 60 housewives.

This study used both primary and secondary data. The primary data mainly were obtained through interviews using structured questionnaire, while the secondary data were obtained from statistical reports and relevant literature. Most of the housewives from case group did not tell their status. In intreview, the data collection was accompanied by the officer from NGO Rumah Matahari. However, the interviews with the housewives from the control group were conducted.

This study examined 13 variables, which were categorized into demographics, sexual behaviour, and sociocultural variables. This categorization refers to the study conducted by Rombo, ${ }^{5}$ who categorized the risk factors of HIV infection among women into those three categories. There were three analysis that were used in this study. Univariate analysis was used to describe to respondents' characteristics. The data were displayed using percentage. The second analysis was bivariate analysis using chi square $\left(\chi^{2}\right)$ and Fisher's exact tests. This analysis was used to analyse the association between the risk factors and HIV infection among housewives. Furthermore, the strength of the association was shown by the odd ratio (OR). The last one was multivariate analysis using logistic regression. This analysis was the continuation of bivariate analysis, in which the variables that had critical $p$ value $<0.25$ in bivariate analysis were involved in the multivariate analysis. The result of logistic regression was a correlation model that was arranged gradually. The final model consisted of variables that had $\mathrm{p}$ value $<0.05$.

\section{Results}

The interviews with the housewives case group revealed that they acquired HIV from their husbands. Most of them realized that they were infected by HIV after their husbands showed the symptoms of AIDS or died due to AIDS. Univariate analysis on the age of housewives showed that those of both groups mostly in their productive age (21-45 years old), where the percentage in the case group was slightly higher than it in the control group. The data from Rumah Matahari revealed that the housewives living with HIV were found in all 21 subdistricts of Pati District. The highest number of housewives living with HIV was found in Pati and Kayen (9 cases in each subdistrict). Moreover, in Jaken and Dukuhseti, the number of housewives living with HIV was 8 cases and 7 cases respectively. This result was in line to the data released by the Pati District Health Office that Pati, Kayen,

Tabel 1. The Risk Factors of HIV Infection among the Housewives (n=90)

\begin{tabular}{|c|c|c|c|c|c|c|c|}
\hline \multirow{2}{*}{ Variables } & \multirow{2}{*}{ Categories } & \multicolumn{2}{|c|}{ Case } & \multicolumn{2}{|c|}{ Control } & \multirow{2}{*}{ OR } & \multirow{2}{*}{ p Value } \\
\hline & & $\mathrm{n}$ & $\%$ & $\mathrm{n}$ & $\%$ & & \\
\hline \multicolumn{8}{|l|}{ Demographic Factors } \\
\hline \multirow[t]{2}{*}{ Age of housewives } & $\leq 49$ years old & 24 & 80.0 & 54 & 90.0 & $0.44(0.130-1.520)$ & 0.188 \\
\hline & $>49$ years old & 6 & 20.0 & 6 & 10.0 & & \\
\hline \multirow[t]{2}{*}{ Age of husbands } & $\leq 49$ years old & 21 & 70.0 & 47 & 78.3 & $0.65(0.239-1.743)$ & 0.386 \\
\hline & $>49$ years old & 9 & 30.0 & 13 & 21.7 & & \\
\hline \multirow[t]{2}{*}{ Housewife's education level } & $\leq 6^{\text {th }}$ grade & 19 & 63.3 & 19 & 31.7 & $3.73(1.485-9.357)$ & 0.004 \\
\hline & $>6^{\text {th }}$ grade & 11 & 36.7 & 41 & 68.3 & & \\
\hline \multirow[t]{2}{*}{ Husband's education level } & $\leq 6^{\text {th }}$ grade & 23 & 76.7 & 23 & 38.3 & $5.29(1.958-14.272)$ & 0.001 \\
\hline & $>6^{\text {th }}$ grade & 7 & 23.3 & 37 & 61.7 & & \\
\hline \multirow[t]{2}{*}{ Income generation activity of housewives } & Yes & 17 & 56.7 & 37 & 61.7 & $0.81(0.334-1.98)$ & 0.648 \\
\hline & No & 13 & 43.3 & 23 & 38.3 & & \\
\hline \multirow[t]{2}{*}{ Husband's occupation } & Outside the area & 23 & 76.7 & 27 & 45.0 & $4.02(1.496-10.777)$ & 0.004 \\
\hline & Inside the area & 7 & 23.3 & 33 & 55.0 & & \\
\hline \multicolumn{8}{|l|}{ Sexual behaviour } \\
\hline \multirow[t]{2}{*}{ Hormonal contraception } & Yes & 22 & 73.3 & 38 & 63.3 & $1.60(0.607-4.177)$ & 0.343 \\
\hline & No & 8 & 26.7 & 22 & 36.7 & & \\
\hline \multirow[t]{2}{*}{ Condom use } & Yes & 4 & 13.3 & 3 & 5.0 & $2.93(0.610-14.010)$ & 0.164 \\
\hline & No & 26 & 86.7 & 57 & 95.0 & & \\
\hline \multirow[t]{2}{*}{ Housewife's record of STDs } & Yes & 4 & 13.3 & 0 & 0.0 & - & 0.004 \\
\hline & No & 26 & 86.7 & 60 & 100.0 & - & \\
\hline \multirow[t]{2}{*}{ Husband's record of STDs } & Yes & 7 & 23.3 & 0 & 0.0 & - & 0.000 \\
\hline & No & 23 & 76.7 & 60 & 100.0 & - & \\
\hline \multicolumn{8}{|l|}{ Socio-cultural factors } \\
\hline \multirow[t]{2}{*}{ Housewife's participation in religious activities } & Yes & 18 & 60.0 & 38 & 62.2 & $0.87(0.353-2.135)$ & 0.758 \\
\hline & No & 12 & 40.0 & 22 & 37.8 & & \\
\hline \multirow[t]{2}{*}{ Husband's participation in religious activities } & Yes & 2 & 6.7 & 19 & 23.3 & $0.15(0.033-0.715)$ & 0.008 \\
\hline & No & 28 & 93.3 & 41 & 76.7 & & \\
\hline \multirow[t]{2}{*}{ Easiness access to prostitution } & Yes & 15 & 50.0 & 30 & 50.0 & $1.000(0.416-2.408)$ & 1.000 \\
\hline & No & 15 & 50.0 & 30 & 50.0 & & \\
\hline \multirow[t]{2}{*}{ Husband's alcohol drinking habit } & Yes & 14 & 46.7 & 9 & 15.0 & $4.96(1.809-13.590)$ & 0.001 \\
\hline & No & 16 & 53.3 & 51 & 85.0 & & \\
\hline
\end{tabular}


Table 2.The Logistic Regression's Model of HIV Infection among Housewives

\begin{tabular}{llllc}
\hline \multicolumn{1}{c}{ Variables } & $\boldsymbol{\beta}$ & $\mathbf{p}$ Value & OR & 95\% CI \\
\hline Husband's education level & 1.684 & 0.002 & 5.385 & $1.871-15.501$ \\
Husband's alcohol drinking habit & 1.624 & 0.004 & 5.072 & $1.692-15.208$ \\
Constanta & -4.456 & 0.001 & & \\
\hline
\end{tabular}

Tayu, and Juwana were the subdistricts that significantly contributed to the number of women living with HIV in Pati District.

Bivariate analysis using chi square test was used to examine the correlation between the HIV infections among housewives with the risk factors of HIV infection as the dependent variables. The result of chi square test is presented in Table 1.

The risk factors that belong to demographic factors significantly associated with HIV infection among housewives were the education level of housewives, the education level of husbands, and the occupation of husbands. The OR of those factors were $3.73(95 \% \mathrm{CI}=$ $1.958-14.272), 5.29(95 \% \mathrm{CI}=1.958-14.272)$, and $4.02(95 \% \mathrm{CI}=1.96-14.27)$ respectively. The sexual behavior factors related to HIV infection among housewives were housewife's sexual transmission diseases (STDs) record and husband's STDs record. The OR for those variables could not be counted due to the presence of the null-value cells. There were two factors affiliated to sociocultural factors significantly associated with HIV infection among housewives, namely husband's participation in religious activities and husband's alcohol drinking habit with the OR was $0.15(95 \% \mathrm{CI}=0.033$ $0.715)$ and $4.96(95 \% \mathrm{CI}=1.809$ - 13.590) respectively. The OR of husband's participation in religious activities had OR less than 1, meaning that the OR in control group was bigger compared to that in the case group. Hence, husband's participation in religious activities could be considered as the inhibiting factor of HIV infection among housewives.

The factors having $\mathrm{p}$ value $<0.25$ were then involved in multivariate analysis using logistic regression. In Table 1 , the factors included in logistic regression were housewife's age, housewife's education level, husband's education level, husband's occupation, housewife's income, the use of condom, housewife's STD records, husband's STD records, husband's participation in religious activities, and husband's alcohol drinking habit. The Hosmer and Lameshow Test valued 0.561 ( $\mathrm{p}$ value $>0.05$ ). It means that there was no difference between empirical and tested data, so the analysis could be continued to the next step. The logistic regression used forward unconditional method and left two variables fitted to the model. The model of logistic regression could predict $73.3 \%$ precisely the HIV infection among housewives cases in Pati
District. The strength of the correlation between the two risk factors and HIV infection among housewives was shown by Nagelkerke $\mathrm{R}^{2}$ valued 0.291 . The final model of logistic regression is presented in Table 2.

Based on Table 2, the two variables associated with HIV infection among housewives in Pati District were husband's education level and husband's alcohol drinking habit. The husband's education level had OR 5.38 (95\% $\mathrm{CI}=1.87-15.50)$, while the husband's alcohol drinking habit had OR 5.07 (95\% CI = 1.692-15.208). Those results meant that the housewives having low-educated husband were likely 5.38 times higher to be infected by HIV compared to those having higher education spouses if only the variable of husbands' alcohol drinking was controlled. Otherwise, the housewives having husbands who used to drinking alcohol were likely to be infected by HIV 5.07 times higher compared to the counterparts if only the variable of education level of spouses was controlled.

\section{Discussion}

From bivariate analysis, the risk factors of HIV infection among housewives in Pati District were housewife's and husband's education levels, husband's occupations, housewife's and husband's records of STDs, husband's participation in religious activities, and husband's alcohol drinking habit. However, there were only two variables fitted to Logistic Regression Model were husband's education level and husband's alcohol drinking habit.

Demographic factors that were significantly proven as the risk factors of HIV infection among housewives in Pati District according to chi-square analysis were housewife's education level, husband's education level, and husband's occupation. In this study, the education level is categorized into lower than the sixth grade and higher than the sixth grade. Univariate analysis showed that the education level of housewives and husbands in the case group were lower compared to the counterparts with the percentage $63.3 \%$ and $31.7 \%$ respectively. The OR for this factor was 3.73 meaning that the lower education housewives with lower education were likely 3.73 times to get HIV compared to those having higher education.

The examination towards husband's education level showed similar result. The percentage of husbands having lower education in the case group was $76.7 \%$. It was higher compared to that of the control group. The OR 
value for the variable was 5.39, meaning that the housewives having lower education husbands tended to be infected by HIV 5.39 times higher than their counterparts. This variable fitted to the model resulted by logistic regression with the OR 5.38 (95\% CI = 1.87-15.50).

The correlation between education level and HIV infection among housewives has been proved by previous study in Nepal. Women having migrant husband who did not ever attend school were likely 5.87 times higher to get HIV. ${ }^{15}$ Meanwhile, the women who had husband never attending school were likely 5 times higher to get HIV. Quinn and Overbaugh, ${ }^{6}$ stated that lower education was one of the roots of women vulnerability toward HIV infection. The education level relates to the knowledge and access to information. The persons with adequate education tend to have more opportunity to access information, so they had knowledge regarding HIV comprehensively. UNAIDS reported that women and girls who attained higher education showed the better sexual and reproductive outcomes. A data analysis from 44 countries showed that women completing secondary education had lower risk of partner violence, particularly in the countries which showed the high rate of spousal abuse. Moreover, the girls with at least six years of school education tend to be more able to protect themselves from HIV infection and other diseases. ${ }^{16}$

The husband's occupation correlated to HIV infection among housewives as well. In this study, most housewives in the case group $(76.7 \%)$ had husbands working long distance jobs, such as domestic migrants, fishermen, drivers, and international labour/migrants with the percentage. Meanwhile, those in the control group were $55 \%$. This study proved that husband's long distance job increased the risk factor for HIV infection due to the wider possibility to leave the families in a longer period, then committing the unsafe sexual behaviour, like accessing prostitution.

This result was in line with the previous study conducted at Dr. Soetomo Surabaya Public Hospital. According to that study, majority of patients living with HIV had high mobility jobs, such as salesmen, drivers, and, waitresses in cafe. ${ }^{17}$ Another study by Johnson and Budlender proved that kinds of informal jobs that obligate the workers to leave their family for a long period, such as mining workers, truck drivers, and security workers had a higher prevalence for getting by HIV than the formal jobs. ${ }^{18}$

STD record correlated with HIV infection among housewives according to bivariate analysis. This study found that $13.3 \%$ housewives and $23.3 \%$ their husbands had STD's records before living with HIV, while those in both control groups were reported none STD's records. However, OR could not be counted due to the null cells in the control group. The kinds of STDs suffered by housewives and their spouses were not elaborated in this study. However, the association of STDs and HIV infection has been proved by several previous studies. Generally. STDs may increase the HIV infection due to the presence of genital infection, which effectively becomes an effective entrance for HIV development. Infections caused by STD break the epithelial surface of the genital tract. That may be the entrance for HIV-1 to target cell under theepithelial surface and to build a systemic infection. ${ }^{19}$ Moreover, the presence of ulcers in both partner cause blood to blood contact thereby transmission.

Several studies revealed the variation of the odd ratio of the correlation between STDs and HIV infection. Miranda et al $^{20}$ reported that the previous sexually transmitted infection (STI) increased the risk of HIV infection (AOR 42.5, 95\% CI = 1.89-168.49). Specifically, Johnson and Lewis, ${ }^{21}$ revealed that infections in genital tract contribute the largest correlation, in which urethritis with OR $3.1(95 \% \mathrm{CI}=1.1-8.6)$ and Cervicitis with OR $2.7(95 \% \mathrm{CI}=1.4-5.2) .{ }^{21}$ A study in South Africa finds that the records of syphilis increase 1.86 times the risk of HIV infection among women. ${ }^{22}$ Meanwhile, another study in Tanzania reported the higher risk. The women having syphilis record were 9 times likely to be infected by HIV. ${ }^{23}$ The infection of syphilis increased the immunity activation of the host, which simultaneously increased the replication of HIV within the cells. Another STD that increase the risk of HIV infection among women is non-ulcerative STDs, like Gonorrhea and Chlamydia. A meta-study by Rotchford et al, ${ }^{24}$ stated that gonorrhea significantly related to HIV infection, while the result was opposite for Chlamydia. However, another study found out that Chlamydia increased 1.8 times the risk factor to HIV infection. ${ }^{21}$

The sociocultural variables that significantly associated with HIV infection among housewives were the husband's participation in religious activities and husband's alcohol drinking habit. The husbands in both case and control group were not active in religious activities. However, the percentage of those in case group was higher $(93.3 \%)$ compared to that in control group $(76.7 \%)$. The OR value for this variable was $0.15(95 \% \mathrm{CI}=$ $0.033-0.715)$. The OR was less than 1 proved that husband's participation in religious activities inhibited the HIV infection among housewives. Otherwise, the housewives having husbands who were not active in religious activities tended to get HIV 6 times higher than their counterparts. This result supported previous study by Kagimu et al, 25 who proved the correlation between religiousity and HIV risk behavior in Uganda. The respondents who used religion identity and committed to religious activities continously prone to avoid risky sexual activities, drug abuse, and alcohol drinking habit. 
Moreover, religiousity increased the life satisfaction and marriage commitment, so that it may inhibit HIV risk behaviors. The other study by Ludema et al, ${ }^{26}$ proved that participation in religious activities, such as reading and learning holy book and the faith to God was a strong barrier for sexual behaviors. ${ }^{26}$ Furthermore, this study also reported that women having a high level of religiosity and spirituality tended to look for partners whose equal qualities to them, in which their partner had a low risk factor of getting HIV as well.

The husband's alcohol drinking habit significantly related to HIV infection among housewives. This study reported that the husband's alcohol drinking habit found in both case and control group, and the case group's percentage was higher $(46.7 \%)$ than that of the control group $(15 \%)$. The OR value was 4.96 , meaning that the housewives having husbands with alcohol drinking habit were likely 4.96 times higher to get HIV than those without alcohol drinking habit. Furthermore, the logistic regression test resulted that this variable together with the husbands' education level fitted to the regression model with the OR $5.072(95 \% \mathrm{CI}=1.692-15.208)$. It meant that both variables simultaneously increased the risk for HIV infection among housewives. However, if the husbands' education level was controlled, the risk value of alcohol drinking habit variable was 5.07. The alcohol consumption did not directly increase the risk for HIV transmission. It increased the prevalence of committing sexual risk behavior that directly related to HIV transmission.

The relation of alcohol consumption to HIV transmission has been reported by several previous studies. Baliunas et al, ${ }^{27}$ proved that $87 \%$ alcohol drinker group committed sexual risk behavior and $77 \%$ of them got HIV. Another study in Peru by Maguina et al, 28 reported that alcohol consumption by both partners increased the prevalence of sexual risk behavior 1.15 times higher. The consumption by the only one partner increased 1.14 times higher the risk for HIV transmission.

\section{Conclusion}

Bivariate analysis resulted that the risk factors for HIV infection among housewives in Pati are housewife's STD records, husband's STD records, husband's participation in religious activities; and husband's alcohol drinking habit. Moreover, logistic regression left two variables fitted to the model, namely husband's education level and husbands' alcohol drinking habit. Both factors simultaneously contribute to $29.1 \%$ HIV infection among housewives in Pati District. Furthermore, the regression model is $73.3 \%$ accurately predicted the HIV infection cases among housewives in the study area. In conclusion, the variables that belong to husband had stronger contribution to HIV infection among housewives.

\section{Recommendation}

The efforts to slow down HIV infections among housewives in Pati District should consider the economic and sociocultural factors of communities. The awareness regarding HIV infection/AIDS should be raised to the groups having higher risks of HIV infection, particularly in the areas dominated by husbands having long-distant jobs and alcoholic drinking habit. Then, the promotion of HIV/AIDS knowledge should be focused on the lower education housewives. The voluntary counselling and testing for HIV should be encouraged among couples that are proven suffering from STDs. The last, the communities should take part in these efforts through the increase of religious activities involving husbands to hamper the spread of HIV infections among housewives.

\section{Acknowledgment}

This study has been funded by the local government of Pati District. Special thanks to the NGO Rumah Matahari that has provided the data of women living with HIV in Pati District and accompanied during the data collection.

\section{References}

1. United Nation of Acquired Immunodeficiency Syndromes (UNAIDS). Factsheet- latest statistics on the status of the AIDS epidemic. 2016. [cited 2017 January 3]. Available at: www.unaids.org/en/resources/factsheet

2. United Nation of Acquired Immunodeficiency Syndromes (UNAIDS). Factsheet 2014 global statistic. 2014. [cited 2017 September 30]. Available at: http://www.unaids.org/sites/default/files/en/ media/unaids/contentassets/documents/factsheet/2014/20140716_FactSheet_en .pdf

3. Kementerian Kesehatan Republik Indonesia. Situasi dan analisis HIV AIDS. Jakarta: Kementerian Kesehatan Republik Indonesia; 2014.

4. Ostrach B, Singer M. At special risk: Biopolitical vulnerability and HIV/STI endemics among women. Health Sociology Review. 2012; 21(3): 258-71.

5. Rombo DO. Marital risk factors and HIV infection among women: a comparison between Ghana and Kenya [dissertation]. Minnesota: The University of Minnesota; 2009.

6. Quinn T, Overbaugh J. HIV/AIDS in women: an expanding epidemic. Science. 2005; 308 (5728): 1582-3.

7. Adaora AA, Ramirez C. Aurbach JD, Aral SO, Hodder S, Wingood G, El-sadr W, Bukusi EA. Preventing HIV infection in women. Journal AIDS. 2013; 63(2). [cited 2016 November 1]. Available at: https://www.ncbi.nlm.nih.gov/pmc/articles/PMC4084712/pdf/nihms4 85473.pdf.

8. Arora U, Chopra S, Jindal N. HIV infection in families in and around Amritsar. Journal Indian Academic of Clinical Medicine. 2008; 9(3): 184-8.

9. Dinas Kesehatan Kabupaten Pati. Profil kesehatan Kabupaten Pati 2013. Pati: Dinas Kesehatan; 2014.

10. Dinas Kesehatan Kabupaten Pati. Profil kesehatan Kabupaten Pati 
2014. Pati: Dinas Kesehatan; 2015.

11. United Nation Women. Beijing declaration and platform for action. Adopted by the United Nation Fourth World Conference on Women: Action for Equality. Beijing: United Nation Women; 1995.

12. Dewi DMSK, Wulandari LPL, Karmaya NM. Kerentanan perempuan terhadap penularan IMS dan HIV: Gambaran perilaku seksual berisiko di Kota Denpasar. Health and Preventive Medicine Archive. 2013; 1(1).

13. World Health Organization. Mother-to-child transmission of HIV. 2016. [cited 2017 June 20]. Available at: http://www.who.int/hiv/ topics/mtct/en/.

14. Muhaimin TB. Prevalensi HIV pada ibu hamil di delapan ibu kota provinsi di Indonesia tahun 2003-2010. Makara Kesehatan. 2011; 15(2): 93-100.

15. Thapa S, Bista N, Timilsina S, Buntinx F, Mathei C. Social behavioural risk factors for HIV infection among the wives of labour migrants in Nepal. International Journal of STD and AIDS. 2014; 25(11): 793 - 9.

16. United Nations Programme on HIV and AIDS. When women lead change happens: Women advancing the end of AIDS. Geneva: United Nations Programme on HIV and AIDS; 2017 [cited 2017 August 13]. Available at: http://www.unaids.org/sites/default/files/media_asset/ when-women-lead-change-happens_en.pdf.

17. Arista A, Murtiastutik D. Studi retrospektif: karakteristik papular pruritic eruption (PPE) pada pasien HIV/AIDS. Berkala Ilmu Kesehatan Kulit dan Kelamin. 2015; 27(3): 204-10.

18. Johnson L, Budlender D. HIV risk factors: A review of the demographic, socio-economic, biomedical and behavioral determinants of HIV prevalence in South Africa. Monograph Report. No. 8. Cape Town: Centre for Actuarial Study University of Cape Town; 2002.

19. Ward H, Ronn M. The contribution of STIs to the sexual transmission of HIV. Current Opinion in HIV and AIDS. 2010; 5(4): 305-10.

20. Miranda AE, Pinto VM, McFarland W, Page K. HIV infection among young pregnant women in Brazil: prevalence and associated risk factors. AIDS Behavior. 2014; 18: 50-2.

21. Johnson LF, Lewis D. The effect of genital tract infection on HVI-1 shedding in the genital tract: a systematic review and meta-analysis. Sexually Transmitted Diseases. 2008; 35(1): 946-59 [cited 2016 November 10]. Available at: http://journals.lww.com/stdjournal/ Fulltext/2008/11000/The_Effect_of_Genital_Tract_Infecti ons_on_HIV_1.11.aspx\#P64.

22. Zuma K, Gouws, E, William B, Lurie M. Risk factors for HIV infection among women in Carletonville, South Africa: migration, demography, and sexually transmitted disease. International Journal of STD and AIDS. 2003; 14 (12): 814-7.

23. Lawi JDT, Mirambo MM, Magoma M, Mushi MF, Jaka HM, Gumadoka $\mathrm{B}$, et al. Sero-conversion rate of syphilis and HIV among pregnant women attending anteranal clinic in Tanzania: A need for re-screening at delivery. BioMed Central Pregnancy and Childbirth. 2015; 15(3): 17.

24. Rotchford K, Sturm AW, Wilkinson D. Effect of coinfection with STDs and of STD treatment on HIV shedding in genital-tract secretions: systematic review and data synthesis. Sexually Transmitted Disease. 2000; 27: $243-8$.

25. Kagimu M, Guwatudde D, Rwabukwali C, Kaye S, Walakira Y, Ainomugisha D. Religiosity for HIV prevention in Uganda: a case study among muslim youth in Wakiso District. Journal of Religion and Health. 2012; 12(3): 282-290.

26. Ludema C, Doherty IA, White BL, Simpson CA, Villar-Loubet O, McLellan-Lemal E, et al. Religiosity and spirituality and HIV risk behaviors among African American women from four rural countries in the Southeastern United States. Journal Health Care Poor Underserved, 2015; 26(1): 168-81.

27. Baliunas D, Rehm J, Irving H, Shuper P. Alcohol consumption and risk of incident human immunodeficiency virus infection: a meta-analysis. International Journal of Public Health. 2010; 55(3): 159-66.

28. Maguina JL, Konda KA, Leon SR, Lescano AG, Clark JL, Hall ER, et al. Relationship between alcohol consumption prior to sex, unprotected sex and prevalence of STI/HIV among socially marginalized men in three coastal cities of Peru. AIDS Behavior. 2013; 17(5): 1724-33. 